\title{
JV TASK 98 - CONTROLLING MERCURY EMISSIONS FOR UTILITIES FIRING LIGNITES FROM NORTH AMERICA
}

Final Report

(for the period February 1, 2006, through June 30, 2007)

Prepared for:

AAD Document Control

U.S. Department of Energy

National Energy Technology Laboratory

PO Box 10940, MS 921-107

Pittsburgh, PA 15236-0940

Cooperative Agreement No. DE-FC26-98FT40321

Project Manager: Eugene Ashby

Prepared by:

Steven A. Benson

Energy \& Environmental Research Center

University of North Dakota

15 North 23rd Street, Stop 9018

Grand Forks, ND 58202-9018 


\section{DISCLAIMER}

This report was prepared as an account of work sponsored by an agency of the United States Government. Neither the United States Government, nor any agency thereof, nor any of their employees makes any warranty, express or implied, or assumes any legal liability or responsibility for the accuracy, completeness, or usefulness of any information, apparatus, product, or process disclosed or represents that its use would not infringe privately owned rights. Reference herein to any specific commercial product, process, or service by trade name, trademark, manufacturer, or otherwise does not necessarily constitute or imply its endorsement, recommendation, or favoring by the United States Government or any agency thereof. The views and opinions of authors expressed herein do not necessarily state or reflect those of the United States Government or any agency thereof.

This report is available to the public from the National Technical Information Service, U.S. Department of Commerce, 5285 Port Royal Road, Springfield, VA 22161; phone orders accepted at (703) 487-4650.

\section{EERC DISCLAIMER}

LEGAL NOTICE: This research report was prepared by the Energy \& Environmental Research Center (EERC), an agency of the University of North Dakota, as an account of work sponsored by the U.S. Department of Energy and the Electric Power Research Institute. Because of the research nature of the work performed, neither the EERC nor any of its employees makes any warranty, express or implied, or assumes any legal liability or responsibility for the accuracy, completeness, or usefulness of any information, apparatus, product, or process disclosed or represents that its use would not infringe privately owned rights. Reference herein to any specific commercial product, process, or service by trade name, trademark, manufacturer, or otherwise does not necessarily constitute or imply its endorsement or recommendation by the EERC. 


\title{
CONTROLLING MERCURY EMISSIONS FOR UTILITIES FIRING LIGNITES FROM NORTH AMERICA
}

\begin{abstract}
This project compiled and summarized the findings and conclusions of research, development, and demonstration projects on controlling mercury from lignite coals. A significant amount of work has been conducted since 1994 on mercury in lignite, mercury measurement in flue gases, sorbent, sorbent enhancement additives, oxidation agent development, and full-scale demonstration of mercury control technologies. This report is focused on providing the lignite industry with an understanding of mercury issues associated with the combustion of lignite, as well as providing vital information on the methods to control mercury emissions in coal-fired power plants.
\end{abstract}




\section{TABLE OF CONTENTS}

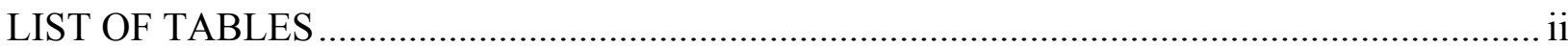

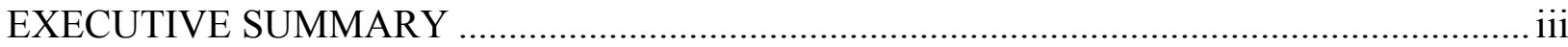

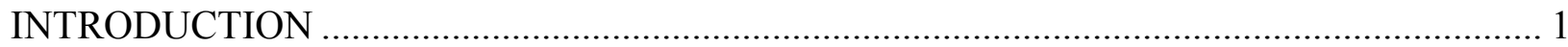

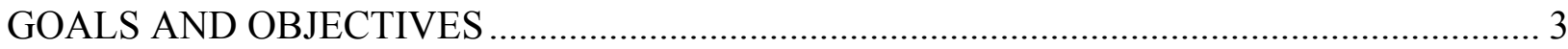

RESULTS … -

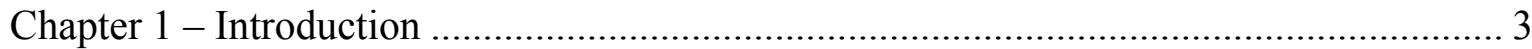

Chapter 2 - Mercury in the Environment and Health .................................................. 3

Chapter 3 - Lignite Characteristics ……………………............................................. 4

Chapter 4 - Lignite Beneficiation .............................................................................. 4

Chapter 5 - Lignite-Fired Power Plants ........................................................................ 5

Chapter 6 - Mercury Transformations and Speciation ……………………………….... 5

Chapter 7 - Mercury Measurement............................................................................... 5

Chapter 8 - Mercury Control Options.............................................................................. 6

Chapter 9 - Mercury Control Testing Results ………………………………………..... 6

Chapter 10 - Mercury in Coal Combustion By-Products ..................................................... 6

Chapter 11 - Summary and Conclusions .......................................................................... 6

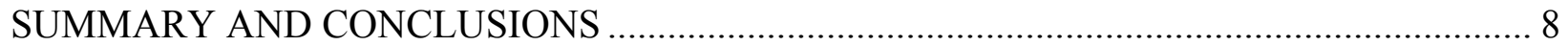

Mercury in the Environment and Health....................................................................... 8

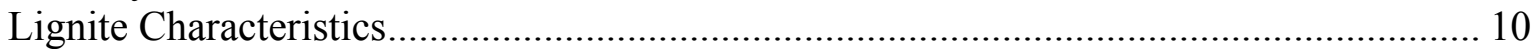

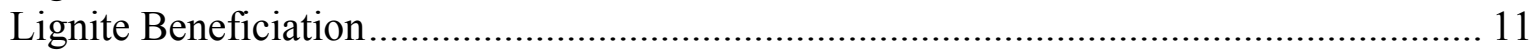

Lignite-Fired Power Plants............................................................................................. 11

Mercury Transformations and Speciation ....................................................................... 12

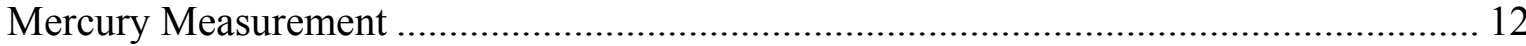

Mercury Control Options ........................................................................................ 14

Mercury Control Testing Results .......................................................................... 16

Mercury in Coal Combustion By-Products .................................................................. 24

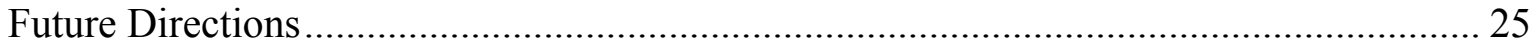

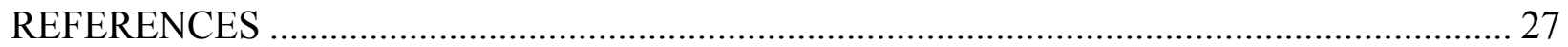




\section{LIST OF TABLES}

1 Mercury Control Testing Completed or under Way ..................................................... 7

2 Average ESP Hg(g) Removal Efficiencies for Sorbents and/or Additives ...................... 15

3 Average SD/FF Hg(g) Removal Efficiencies for Sorbents and/or Additives ................... 15

4 Average ESP/Advanced Hybrid ${ }^{\mathrm{TM}}$ Filter $\mathrm{Hg}(\mathrm{g})$ Removal Efficiencies for Sorbents

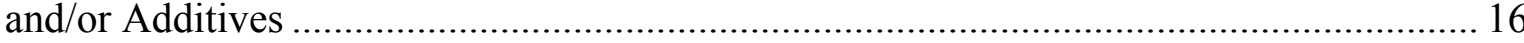




\section{CONTROLLING MERCURY EMISSIONS FOR UTILITIES FIRING LIGNITES FROM NORTH AMERICA}

\section{EXECUTIVE SUMMARY}

Mercury is a multimedia pollutant that is emitted, deposited and reemitted on both a local and a global scale in both terrestrial and marine environments. The lifetime of $\mathrm{Hg}^{0}$ in the atmosphere is estimated to be up to a year, while oxidized forms have a lifetime of only a few days because of particulate settling and solubility. Elemental mercury can be transported over transcontinental distances, whereas oxidized gaseous and particulate forms are deposited near their source. Globally, Asian countries, particularly China and India, put half the new mercury into the atmosphere yearly and are rapidly increasing their output of the substance. North American sources overall are only about $9 \%$ of the global total and are declining over time. Emissions by other continents are generally increasing, while North America and Europe are declining.

The unique composition of lignite coals due to low-chlorine $(<50 \mathrm{ppm})$ coal combustion flue gases (typical of lignite) contain predominantly $\mathrm{Hg}^{0}$, which is substantially more difficult to remove than $\mathrm{Hg}^{2+}$. Mercury control testing was conducted at selected plants based on the lignite characteristics and characteristics of air pollution control devices. Options for mercury control in existing coal-fired power plants consisted mainly of the enhancement of existing air pollution control systems and the addition of new multipollutant control options such as fabric filters. Enhancement of existing air pollution control devices includes sorbent injection with and without sorbent enhancement agents upstream of existing particulate control systems and mercury oxidation upstream of wet and dry scrubbers.

The use of sorbent and/or activated carbon injection as a means of removing mercury from lignite combustion flue gas is widely accepted as the most developed and commercially viable method. Application of sorbent injection in coal-fired utility boilers is very challenging because of lower concentrations of mercury and the range of mercury forms in coal combustion flue gases. Their effectiveness depends on coal type and power plant configuration.

Mercury transformations and speciation are keys to identifying, developing, and utilizing effective mercury control technologies. The chemical reactions of mercury in the flue gas with other gaseous components and entrained-ash species impact the mercury speciation in the flue and the effectiveness of the control technology. The mechanisms involve both homogeneous and heterogeneous reactions of mercury in flue gas, entrained-ash particles, and sorbents. The injection of chemicals and finely powdered sorbent injection upstream of a particulate collection device has the potential to capture both $\mathrm{Hg}^{0}$ and $\mathrm{Hg}^{2+}$ present in the flue gas. 


\section{CONTROLLING MERCURY EMISSIONS FOR UTILITIES FIRING LIGNITES FROM NORTH AMERICA}

\section{INTRODUCTION}

The quantity of mercury mobilized and released into the environment has increased since the beginning of the industrial age. Mercury is a leading concern among the air toxic metals addressed in the 1990 Clean Air Act Amendments because of its volatility, persistence, and bioaccumulation as methylmercury in the environment and its neurological health impacts. After most industrial, medical, and household uses of mercury are eliminated, coal-fired utility boilers were identified as the largest remaining source of mercury in the United States. Much of the contamination to the aquatic environment has been attributed to atmospheric mercury sources (1). Fifty percent of the atmospheric sources are because of anthropogenic activities. Mercuryspecifically methylmercury - has been identified as a neurotoxin with the highest potential for negative health effects on the developing fetus and children (2). Fish consumption is the dominant pathway for human and wildlife exposure to mercury. In December 1997, the Mercury Study Report to Congress (3) provided an assessment of the magnitude of U.S. mercury emissions by source, the health and environmental implications of those emissions, and the availability and cost of control technologies.

Both natural and anthropogenic processes have an impact on the global mercury cycle. There are several forms of mercury in the environment, including elemental mercury (gas), ionic mercury (gas), inorganic mercury salts (solids), and organic mercury (i.e., methylmercury). Mercury in the atmosphere is mostly in the elemental form; however, some is present in the ionic form. The elemental form can remain in the atmosphere for as long as a year and can be transported thousands of miles from its source prior to deposition. The primary method of mercury deposition is through wet deposition (4) from the atmosphere to surface water and land. Dry deposition can also occur. The ionic and particulate form of atmospheric mercury is less likely to be transported long distances and will be deposited close to the source through wet and dry deposition. After deposition, there is also evidence of mercury cycling between the atmosphere, land, and water; this process is not completely understood. Upon deposition, mercury can be methylated, which is considered the key step in the entrance of mercury into the food chain (4). The methylation process from inorganic mercury is a biotransformation process that occurs in the sediments and the water (3). Once in the form of methylmercury, it is transferred to planktivorous and piscivorous fish through their diets (3). Methylmercury in smaller fish is passed up the food chain and accumulated in the muscle tissue of fish.

Concern over potential human health risks associated with chemically contaminated fish and shellfish has led many states to issue consumption advisories and bans in an effort to limit exposures to certain organic compounds and metals that may become concentrated in the tissues of these fish. The consumption of fish is highly variable across the U.S. population. Information regarding fish consumption among the general U.S. population is compiled in Volume IV of the 
Mercury Study Report to Congress (3). The inclusion of fish in diets varies with geographic location, seasons of the year, ethnicity, and personal food preferences. Jacobs and others (5), in an analysis of the U.S. Department of Agriculture (USDA) Continuing Survey of Food Intake by Individuals (CSFII) (6-8), estimated food consumption rates for three fish habitats: freshwater/estuarine fish, marine, and all fish. The estimated fish consumption rates for all fish for the U.S. population was 15.65 grams/person/day, with 4.71 grams/person/day from freshwater/estuarine sources and 10.94 grams/person/day from marine sources. The average consumption rate for women aged 18-45 years from all sources was found to be 14.25 grams/person/day. The results were reported on an as-consumed basis, with consideration given for weight loss or weight gain during cooking.

Mercury regulations from coal-fired power plants in both the United States and Canada are being developed. The U.S. Environmental Protection Agency's (EPA's) proposed Utility Mercury Reduction Rule and Canada's Canada-Wide Standards (CWS) illustrate the need for effective mercury control strategies for coal-fired electric utilities. Sorbent injection upstream of a particulate control device is the retrofit technology that has demonstrated the widest application for mercury control in plants not equipped with flue gas desulfurization (FGD) scrubbers.

On March 15, 2005, EPA announced the new Clean Air Mercury Rule (CAMR) for coalfired power plants. The rule makes the United States the first country in the world to regulate mercury emissions from coal-fired power plants. It was EPA's decision to regulate mercury under Sections 110(a)(2)(D) and 111 rather than Section 112 of the Clean Air Act. Under Section 111, a cap-and-trade rule was established. The CAMR is viewed by EPA to function in conjunction with the Clean Air Interstate Rule (CAIR) to reduce mercury emissions nationwide. It is expected that the additional wet FGD (WFGD) and selective catalytic reduction (SCR) systems that will be installed to comply with the CAIR $\mathrm{SO}_{2}$ and $\mathrm{NO}_{\mathrm{x}}$ requirements in 28 eastern states will provide a substantial mercury cobenefit.

Based on the 1997 Information Collection Request (ICR) data, it has been established that current U.S. mercury emissions from coal-fired electric utilities is 48 tons a year. The cap-andtrade provision of the new rule would reduce that amount to 38 tons of mercury a year in 2010, a reduction of $20.8 \%$. It is fully expected that the addition of new WFGD and SCR systems to reduce $\mathrm{SO}_{2}$ and $\mathrm{NO}_{\mathrm{x}}$ under CAIR will allow the states to meet the 2010 mercury reduction requirements without additional mercury controls. By 2018, coal-fired power plants will be required to make further reductions to 15 tons a year, a total reduction of $68.8 \%$ from 1997 emissions. To ensure the required mercury reduction is met and to facilitate trading, the EPA has established emission budgets for each state based on the baseline heat input adjusted for the coal burned for each plant in a given state.

The mercury technologies currently being tested include the following:

- Activated carbon sorbent technologies and control in unscrubbed systems

- Mercury oxidation and sorbent injection for scrubbed systems 
- Multipollutant control strategies

This report compiles and summarizes the findings and conclusions of research, development, and demonstration projects on controlling mercury from lignite coals. A significant amount of work has been conducted since 1994 on mercury in lignite, mercury measurement in flue gases, sorbent, sorbent enhancement additives (SEA), oxidation agent development, and full-scale demonstration of mercury control technologies. This report is focused on providing the lignite industry with an understanding of mercury issues associated with the combustion of lignite, as well as providing vital information on the methods to control mercury emissions in coal-fired power plants.

\section{GOALS AND OBJECTIVES}

The goal of this project is to provide a report in book format that will summarize the findings and conclusions of research, development, and demonstration projects on controlling mercury from lignite coals. The specific objectives of the project will include:

- Identification and compilation of key literature and background information relevant to mercury control for lignites

- Development of a detailed outline for the report that is reviewed and approved by project sponsors

- Preparation of a report that will include a draft version for review by project sponsors and incorporation of comments and changes made by reviewers in the final version

- Printing and distribution of the report

\section{RESULTS}

The report is divided into the following chapters.

\section{Chapter 1 - Introduction}

This section provides an overview of the scope of the report. The report content is based on literature and project reports specifically aimed at mercury control for lignite coals of North America.

\section{Chapter 2 - Mercury in the Environment and Health}

This section describes the fate and behavior of mercury in the environment. The discussion will focus on mercury as a pollutant that is emitted, deposited, and reemitted on both a local and a global scale in both terrestrial and marine environments. The current level of understanding of 
this complex interplay of emission, transport, deposition, and recycling of different forms of mercury will be addressed, along with a discussion of efforts by modelers to correlate particular atmospheric emission sources with human exposure.

The accumulation of mercury in various foods is discussed. Specific emphasis will be placed on the variability in the availability of mercury once deposited. For example, some of the $\mathrm{Hg}^{2+}$ forms stable complexes which are biologically unavailable, while the rest is accumulated by organisms, particularly in aquatic environments. Aspects of the aquatic environment that influence biota production rates will also affect mercury bioaccumulation. Multiple factors such as sulfate and selenium (Se) availability exert both direct and indirect concentration-dependent effects on mercury bioaccumulation (9).

The exposure of the people in Minnesota and North Dakota to mercury through fish consumption is described in detail. The consumption of predatory fish can cause adverse effects in highly exposed and sensitive populations. Fish consumption is the most significant source of human exposure to methylmercury in the United States. Mercury poisoning through consumption of fish has been well documented, and limits of exposure have been determined by EPA (3). The National Research Council Committee on Toxicological Effects of Methylmercury found that the EPA reference dosage (RfD) for human exposure to methylmercury of $0.1 \mu \mathrm{g} / \mathrm{kg}$ per day is scientifically sound for the protection of human health (10).

\section{Chapter 3 - Lignite Characteristics}

In general, lignitic coals are unique because of their highly variable ash content, which is rich in alkali and alkaline-earth elements; high oxygen and moisture levels; and low chlorine content. Lignite coals typically contain comparable levels of mercury but significantly lower levels of chlorine compared to bituminous coals. Lignites have chlorine concentrations well below 200 ppm in the coal, whereas Appalachian and Illinois Basin bituminous coals can have chlorine levels in excess of $1000 \mathrm{ppm}$. These differences in composition have important effects on the form of mercury emitted from a boiler and the capabilities of different control technologies to remove mercury from flue gas.

\section{Chapter 4 - Lignite Beneficiation}

Removal of mercury from the fuel prior to combustion is a mercury control approach that has been considered for many years. Washing of bituminous coals for the removal of pyrites and other mineral matter results in the removal of some of the mercury, however, not to the extent that would be needed to meet future control requirements. Coal washing for ash reduction has proven to be effective primarily for bituminous fuels with large mineral grains. With subbituminous and lignite fuels, conventional coal washing is not effective because of the way the inorganic material is distributed within the coal. For subbituminous coals, deep cleaning or pretreatment of the coal, such as with the K-Fuel ${ }^{\circledR}$ and Western Research Institute (WRI) thermal processes, has the potential to remove a significant fraction of the mercury. A review of these 
developments is presented in this report. Another fuel-upgrading project, conducted by Great River Energy with funding from the U.S. Department of Energy (DOE), is to evaluate the drying of a high-moisture North Dakota lignite at the large-scale level. The process does not claim to remove mercury from the lignite but upgrades the fuel with waste heat, resulting in overall plant efficiency improvement, with some subsequent reduction in mercury emissions. However, even with mild thermal processing of a raw fuel, there is potential for removing some of the mercury along with the moisture by increasing the drying temperature.

\section{Chapter 5 - Lignite-Fired Power Plants}

An overview of lignite-fired power plants where mercury control testing has been conducted in North America is provided. This will include coal type fired, boiler type, and associated air pollution control devices.

\section{Chapter 6 - Mercury Transformations and Speciation}

This chapter will describe the influence that the unique composition of lignite coals has on mercury transformation and speciation in flue gases. The specific focus of the chapter will be on results that show low-chlorine $(<50 \mathrm{ppm})$ coal combustion flue gases (typical of lignite) contain predominantly $\mathrm{Hg}^{0}$, which is substantially more difficult to remove than $\mathrm{Hg}^{2+}$ (1). Additionally, the generally high alkali and alkaline-earth content of lignite coals reduces the oxidizing effect of the already-low chlorine content by reactively scavenging chlorine species $\left(\mathrm{Cl}, \mathrm{HCl}\right.$, and $\left.\mathrm{Cl}_{2}\right)$ from the combustion flue gas. The level of chlorine in flue gases of recently tested lignites from North Dakota and Saskatchewan ranged from 2.6 to $3.4 \mathrm{ppmv}$, with chlorine content ranging from 11 to $18 \mathrm{ppmw}$ in the coal on a dry basis, respectively.

\section{Chapter 7 - Mercury Measurement}

The most common approach for measuring mercury emissions from anthropogenic point sources, such as coal-fired utilities, is to extract a representative sample of the flue gas using a sampling train. Sampling trains generally consist of an isokinetic nozzle and a filter to collect a representative fly ash sample and a liquid or solid sorption system to collect a particulate-free gaseous sample. In addition to impinger-based sampling trains, gaseous mercury species $\left(\mathrm{Hg}^{2+}\right.$ and $\mathrm{Hg}^{0}$ ) can be selectively captured on solid sampling medium through adsorption, amalgamation, diffusion, and ion exchange processes.

The challenges of mercury continuous emission monitors (CEMs) will be discussed. Emphasis will be placed on the ability to perform measurement under typical CEM condition requirements that include long-term, low-maintenance, continuous operation for flue gas mercury monitoring. The two main challenges include the areas of sample collection and flue gas conditioning. Collecting a representative flue gas sample for mercury analysis from coal combustion flue gas can be very difficult. 


\section{Chapter 8 - Mercury Control Options}

This chapter will describe the most cost-effective approaches to controlling mercury emissions. These methods include enhancement of existing air pollution control equipment to control mercury emissions. Applications include cold-side electrostatic precipitators (c-ESP), various types of wet FGD systems, and spray dryer absorbers-fabric filter (SDA-FFs). All of the efforts described involve the evaluation of selected types of additive, reagent, or sorbent for its potential to control mercury emissions in conjunction with existing air pollution control technology or to modify mercury speciation in the flue gas to facilitate mercury control. Most of the projects involve the injection of some form of activated carbon into the flue gas stream. Several projects involve the use of additives to wet FGD systems to improve mercury emission control. The mechanisms of reaction and interaction of sorbents, oxidants, and sorbent enhancement agents with mercury species will be described.

\section{Chapter 9 - Mercury Control Testing Results}

The mercury control testing currently under way and completed are described in Table 1 . The technologies utilized are also described. All of these projects involve the evaluation of some type of additive, reagent, or sorbent for its potential to control mercury emissions in conjunction with existing air pollution control technology or modify mercury speciation in the flue gas to facilitate mercury control. Most of the projects involve the injection of some form of activated carbon into the flue gas stream. Several projects involve the use of additives to wet FGD systems to improve mercury emission control. Other approaches include coal blending or the addition of fuel additives to affect mercury speciation and control.

\section{Chapter 10 - Mercury in Coal Combustion By-Products}

Mercury emission control technologies are being developed to remove mercury from the flue gases, and in many cases, these technologies are designed to incorporate the mercury removed from the flue gas into the fly ash or FGD material. The stability of mercury associated with coal combustion by-products (CCBs) is an issue that has only recently come under investigation, but it has become a prominent question as the industry strives to develop and test mercury emission controls that may consequently increase the mercury associated with CCBs. The primary reason for evaluating the rerelease of mercury from CCBs is to aid utilities in determining and understanding changes in CCBs associated with mercury control and how these changes may impact CCB management.

\section{Chapter 11 - Summary and Conclusions}

This chapter will describe the status of mercury control and the next steps to controlling mercury emissions. 
Table 1. Mercury Control Testing Completed or Under Way*

\begin{tabular}{|c|c|c|c|c|c|}
\hline Lead Contractor & Demonstration Site & Boiler Type/Size & Fuel Type & APCD & $\begin{array}{l}\text { Mercury Control } \\
\text { Technology }\end{array}$ \\
\hline UND EERC & $\begin{array}{l}\text { Leland Olds Station Unit } 1 \\
\text { Basin Electric Power Cooperative }\end{array}$ & $\begin{array}{l}\text { B\&W wall fired } \\
220 \mathrm{MW}\end{array}$ & ND lignite & c-ESP & ACI with SEA \\
\hline ADA-ES Inc. & $\begin{array}{l}\text { Coal Creek Station Unit } 1 \\
\text { Great River Energy }\end{array}$ & $\begin{array}{l}\text { CE t fired } \\
546 \mathrm{MW}\end{array}$ & ND lignite & $\begin{array}{l}\text { c-ESP } \\
\text { Wet FGD }\end{array}$ & TOXECON II ${ }^{\mathrm{TM}}$ \\
\hline URS & $\begin{array}{l}\text { Stanton Station Unit } 1 \\
\text { Great River Energy }\end{array}$ & $\begin{array}{l}\text { FW wall fired } \\
150 \mathrm{MW}\end{array}$ & PRB & c-ESP & $\mathrm{ACI}$ \\
\hline URS & $\begin{array}{l}\text { Stanton Station Unit } 10 \\
\text { Great River Energy }\end{array}$ & $\begin{array}{l}\text { CE t fired } \\
60 \mathrm{MW}\end{array}$ & ND lignite & SDA-FF & $\mathrm{ACI}$ \\
\hline $\begin{array}{l}\text { SaskPower and } \\
\text { UND EERC }\end{array}$ & $\begin{array}{l}\text { Poplar River Power Station Units } 1 \\
\text { and } 2 \\
\text { SaskPower }\end{array}$ & $\begin{array}{l}\text { NA } \\
300 \mathrm{MW}\end{array}$ & $\begin{array}{l}\text { Poplar River } \\
\text { lignite }\end{array}$ & c-ESP & $\begin{array}{l}\text { ACI } \\
\text { Pilot-scale slipstream }\end{array}$ \\
\hline UND EERC & $\begin{array}{l}\text { Antelope Valley Station Unit } 1 \\
\text { Basin Electric Power Cooperative }\end{array}$ & $\begin{array}{l}\text { CE t fired } \\
440 \mathrm{MW}\end{array}$ & ND lignite & SDA-FF & $\begin{array}{l}\text { ACI } \\
\text { ACI with SEA }\end{array}$ \\
\hline UND EERC & $\begin{array}{l}\text { Milton R. Young Station Unit } 2 \\
\text { Minnkota Power Cooperative }\end{array}$ & $\begin{array}{l}\text { B\&W cyclone } \\
\text { fired } 450 \mathrm{MW}\end{array}$ & ND lignite & $\begin{array}{l}\text { c-ESP } \\
\text { Wet FGD }\end{array}$ & $\begin{array}{l}\text { Mercury oxidation } \\
\text { fuel/FG additives }\end{array}$ \\
\hline UND EERC/URS & $\begin{array}{l}\text { Monticello Station Unit } 3 \\
\text { Texas Utilities Company }\end{array}$ & $\begin{array}{l}\text { B\&W wall fired } \\
750 \mathrm{MW}\end{array}$ & Texas lignite & $\begin{array}{l}\text { c-ESP } \\
\text { Wet FGD }\end{array}$ & $\begin{array}{l}\text { Mercury oxidation } \\
\text { fuel/FG additives }\end{array}$ \\
\hline UND EERC & $\begin{array}{l}\text { Big Brown Station } \\
\text { Texas Utilities Company }\end{array}$ & $\begin{array}{l}\text { CE } t \text { fired } \\
600 \mathrm{MW}\end{array}$ & $\begin{array}{l}\text { Texas lignite } \\
\text { Lignite-PRB }\end{array}$ & c-ESP & $\mathrm{ACI}$ \\
\hline URS & $\begin{array}{l}\text { Monticello Station Unit } 3 \\
\text { Texas Utilities Company }\end{array}$ & $\begin{array}{l}\text { B\&W wall fired } \\
750 \mathrm{MW}\end{array}$ & Texas lignite & $\begin{array}{l}\text { c-ESP } \\
\text { Wet FGD }\end{array}$ & Wet FGD additives \\
\hline $\begin{array}{l}\text { ALSTOM Power, } \\
\text { Inc. }\end{array}$ & $\begin{array}{l}\text { Leland Olds Station Unit } 1 \\
\text { Basin Electric Power Cooperative }\end{array}$ & $\begin{array}{l}\mathrm{B} \& \mathrm{~W} \\
440 \mathrm{MW} \\
\end{array}$ & ND lignite & c-ESP & ACI with additives \\
\hline \multicolumn{2}{|c|}{$\begin{array}{ll}* \text { ACI - activated carbon injection } & \text { FGI } \\
\text { ADA-ES Inc. - ADA Environmental Solutions Inc. } & \text { FW } \\
\text { B\&W - Babcock \& Wilcox Company } & \text { NA } \\
\text { CE - Combustion Engineering } & \text { PRF } \\
\text { c-ESP - cold-side electrostatic precipitator } & \text { SD }\end{array}$} & $\begin{array}{l}\text { lue gas desulfurization } \\
\text { ster Wheeler } \\
\text { t available } \\
\text { owder River Basin sul } \\
\text { - spray dryer absorbe }\end{array}$ & $\begin{array}{l}\text { ituminous coal } \\
\text { fabric filter }\end{array}$ & $\begin{array}{l}\text { SEA - } \\
\mathrm{t} \text { fired } \\
\text { UND } \\
\text { Envi } \\
\text { URS - }\end{array}$ & $\begin{array}{l}\text { bent enhancement additive } \\
\text { ingentially fired } \\
\text { RC - University of North Dakota Energy \& } \\
\text { mental Research Center } \\
\text { RS }\end{array}$ \\
\hline
\end{tabular}




\section{SUMMARY AND CONCLUSIONS}

\section{Mercury in the Environment and Health}

Mercury is a multimedia pollutant that is emitted, deposited, and reemitted on both a local and a global scale in both terrestrial and marine environments. The lifetime of $\mathrm{Hg}^{0}$ in the atmosphere is estimated to be up to a year, while oxidized forms have a lifetime of only a few days because of particulate settling and solubility. Elemental mercury can be transported over transcontinental distances, whereas oxidized gaseous and particulate forms are deposited near their source. Globally, Asian countries, particularly China and India, put half of the new mercury into the atmosphere yearly and are rapidly increasing their output of the substance. North American sources, overall, are only about $9 \%$ of the global total and are declining over time. Emissions by other continents are generally increasing, while North America and Europe are declining. The quantity of mercury mobilized and released into the environment has increased since the beginning of the industrial age. Much of the contamination to the aquatic environment has been attributed to atmospheric mercury sources. The atmospheric sources are largely because of anthropogenic activities.

The modeling efforts to determine the atmospheric fate, transport, and deposition of mercury indicate that over $80 \%$ of the mercury deposited in the United States is from international sources. The remaining $20 \%$ is from U.S. and Canadian sources. Significant variability in mercury deposition is noted across the United States based on the modeling efforts. The domestic sources in the eastern United States have much more of an impact on the mercury deposition in that part of the United States, while global sources were found to be the major source of mercury deposition in the western United States.

Mercury - specifically methylmercury - has been identified as a neurotoxin and has the highest potential health effects on the developing fetus and children. In December 1997, the Mercury Study Report to Congress provided an assessment of the magnitude of U.S. mercury emissions by source, the health and environmental implications of those emissions, and the availability and cost of control technologies. A congressionally mandated reassessment of the toxicological effects of mercury issued by the National Research Council (NRC) in August 2000 reaffirmed the EPA's mercury exposure RfD of $0.1 \mu \mathrm{g} / \mathrm{kg}$ per day as the scientifically justifiable level for the protection of public health.

The fate of mercury precipitates will partially depend upon whether they have fallen onto land or water surfaces. In both cases, sunlight-dependent photoreduction can result in reformation of $\mathrm{Hg}^{0}$ that is emitted back into the air to rejoin the global pool. A variable portion remains in the oxidized form and is retained where it falls. Certain quantities of retained $\mathrm{Hg}^{2+}$ form stable complexes that are biologically unavailable, while the rest is accumulated by organisms. The estimate for conversion to methylmercury is $0.03 \%$. When mercury accumulation rates exceed the capacity of natural mechanisms to release it back into the atmosphere or geologically retire it from active cycling, mercury concentrations build up in aquatic biota. Certain bacteria employ a biochemical pathway (methylation) that creates methylmercury $\left(\mathrm{CH}_{3} \mathrm{Hg}\right)$, the predominant form of mercury that bioaccumulates in organisms of 
the food web. Methylmercury typically constitutes the bulk of the total mercury in an organism, although biologically inert forms of mercury can also accumulate in tissues.

The contrasting observations reported by studies of mercury exposure performed in fisheating populations of the Seychelles and the Faroe Islands may be related to differences in the patterns of mercury exposure of their respective study populations. In the Seychelles, no adverse associations have been noted among a population consuming large quantities of fish with typically low mercury levels. In certain measurements of neurodevelopmental outcomes, fish consumption by Seychellois mothers during pregnancy was associated with beneficial effects on their children, possibly as a result of improved nutritional status. These results contrast with those found in the Faroe Islands, which reported adverse associations from prenatal $\mathrm{CH}_{3} \mathrm{Hg}$ exposure. Although adult Faroe Islanders consume $\sim 72 \mathrm{~g}$ of fish a day, the fish they consume have relatively low mercury contents: $\sim 0.07 \mathrm{ppm}$. Only $\sim 10 \%$ of the mercury they consume comes from fish. Averaged daily consumption of $\sim 12-\mathrm{g}$ portions of pilot whale muscle meat with mercury contents of $3.3 \mathrm{ppm}$ and intermittent consumption of pilot whale organ meats with mercury contents that can be more than 10-fold higher provide the bulk of mercury exposure in this population. Thus more than $90 \%$ of mercury exposure in the Faroe Islands arises from the consumption of whale meat. One potential explanation of these contradictory observations is that the studies in the Faroe Islands and the Seychelles may be observing differences in the dangers of intermittent exposures to high concentrations of mercury in whale meat versus consistent lowlevel mercury exposures that accompany fish consumption.

A fish consumption survey was conducted for Minnesota and North Dakota residents for the following categories: general population (white and other), Bois Forte Tribe (Minnesota), Spirit Lake Nation and Three Affiliated Tribes (North Dakota), respondents with and without fishing licenses, children, women of childbearing age (15-44 years), women ( $>44$ years), and men. The estimated mercury exposure for the adults determined for both Minnesota and North Dakota is very similar to mercury exposures reported by EPA. The results of the comparisons of the estimated mercury exposure for children are also very similar. In order to validate the fish consumption survey results, analysis of hair samples from selected women of childbearing age indicate low levels of mercury, ranging from 0.01 to $0.64 \mu \mathrm{g} / \mathrm{g}$. The estimated mercury exposure through fish consumption was found to be 5 to 6 times higher than the levels determined from the hair analysis. However, a strong correlation exists between the levels of mercury in hair and estimated mercury exposure based on survey data. This suggests that the survey overestimates the exposure to mercury through fish consumption. The impact of the presence of selenium in the diets of residents of North Dakota and Minnesota was identified as a potential contributor to the lower levels of mercury found in the hair. Selenium has a strong affinity for mercury and will bond to it in the body.

Conflicting observations and conclusions have arisen from the ongoing studies of mercurydependent health effects in the Faroe Islands and in the Seychelles Islands. While researchers in the Faroe Islands reported neurological defects in children exposed to low levels of mercury in the womb, the Seychelles study has found no adverse effects from prenatal methylmercury exposure, even at levels of exposure 10-20 times higher than what is common in the United States. In further contrast, maternal fish consumption in the Seychelles correlated with an improved neurodevelopmental outcome in some indexes. The discrepancies between the 
observations and conclusions reported in these studies may be because of dietary differences in the study populations. The protective effect of selenium against mercury toxicity may be one dietary factor and is currently being assessed in laboratory animals. The influence of dietary selenium on mercury accumulation in the brain was also dramatic. Mercury contents in brains of rats fed diets containing $2.5 \mu \mathrm{mol} \mathrm{MeHg} / \mathrm{g}$ were $5.1 \pm 0.7 \mu \mathrm{mol} \mathrm{Hg} / \mathrm{kg}$ in rats fed seleniumdeficient diets but almost twice as high when rats were fed selenium-adequate and four times greater when fed selenium-enriched diets. Mercury contents in brains of rats fed diets containing $75 \mu \mathrm{mol} \mathrm{MeHg} / \mathrm{g}$ were $94.3 \pm 8.3 \mu \mathrm{mol} \mathrm{Hg} / \mathrm{kg}$ in rats fed selenium-deficient diets and were unchanged when rats were fed selenium-adequate diets. However, brain mercury contents almost doubled among rats fed selenium-enriched diets.

In addition, selenium and mercury analyses are being included as concomitant variables regarding neurodevelopmental assessment end points for the children born to mothers with known exposures to methylmercury from fish. The EERC measured selenium in whole-blood samples collected from 250 maternal-fetal pairs from the current Seychelles study. These values will be assessed in concert with dietary records from the individual subjects and analytical data reflecting blood mercury contents. The blood concentrations of omega-3 fatty acids, mercury, and selenium will be examined in relation to neurodevelopment assessed in the children. Adding to the controversy, a recent report published in Lancet indicated that children born to mothers who consumed more than $340 \mathrm{~g} /$ week of fish had better neurodevelopment outcomes than mothers who limited their intake to less than $340 \mathrm{~g} / \mathrm{week}$.

\section{Lignite Characteristics}

The inorganic constituents or impurities present in lignitic coals include major, minor, and trace elements. These inorganic elements are present in lignite in a wide range of associations that consist of cations associated with oxygen functional groups and clay minerals; coordinated inorganic elements; water-soluble elements present in water associated with the lignite; and discrete mineral grains such as clays, sulfides, carbonates, oxides, and sulfates. The abundance and association of inorganic elements in coals vary significantly with rank. The inorganic components of higher-ranked coals, bituminous and anthracitic, consist mainly of minerals. Lignitic and subbituminous coals have high levels of oxygen, which act as bonding sites for cations such as sodium, magnesium, calcium, potassium, strontium, and barium (other minor and trace elements may also be present in this form).

The quantities of mineral phases present in coals cover a wide range of values and are dependent upon the depositional environment of each coal. Many of these minerals are of detrital origin, meaning that they have been carried in by wind and water and deposited. The major species in this group are the silicate minerals, including quartz and clays. Authigenic minerals form during and after coal deposition by a variety of mechanisms, including bacterial action, groundwater flow, and reducing and oxidizing reactions. These minerals include sulfides, sulfates, oxides, and carbonates. All of these factors influence the way minerals incorporate themselves into the organic matrix of the coal and ultimately influence their transformations during combustion or other utilization processes. 
The minor and trace elements in coals are associated in several forms in the lignitic coals. Similar to the major inorganic components, the trace elements are associated with the organic as well as the mineral component of the lignite. The mode of occurrence of mercury indicates a clear inorganic association with pyrite minerals in lignite. However, there is some evidence of an organic association of some of the mercury.

\section{Lignite Beneficiation}

\section{Air Jig Testing}

The results of this study indicate that the air jig is capable of reducing the ash, sulfur, and mercury content of lignite coals while increasing the overall heating value. In general, coals with higher ash contents will benefit more from the air jig process than coals with lower ash contents. Pyrite compounds are significantly reduced in the air jig process. This results in reduced mercury concentration in the coal and, in some cases, a lower potential for boiler fouling and slagging problems.

\section{Thermal Treatment Process}

The WRI process has shown the ability to remove mercury from coal prior to combustion using thermal technology. The technology has been tested for lignite and subbituminous coals. In addition to the removal of mercury, it also removes all the moisture in the first stage of the twostage process. By removing water in the first stage, the mercury and possibly other trace elements evolved during the second stage do not contaminate the water, thus negating a water cleanup challenge. The mercury removal ranged from $50 \%$ to $57 \%$ for lignite and $60 \%$ to $80 \%$ for PRB subbituminous coal.

The K-Fuel process is a thermal technology that removes moisture and mercury. The technology utilizes a Mark IV Lurgi fixed-bed gasifier that processes the coal at $460^{\circ} \mathrm{F}$ and 485 psi with steam. This process results in the vaporization of water and mercury as well as some sulfur. The mercury was reported as $70 \%$ or greater. The literature indicated that the process does fracture some of the pyrite. This enables the removal of pyrite that may contain mercury in a subsequent screening process. The mercury that is removed includes primarily organic; however, through cleaning and possibly through the reaction of the pyrite with steam under pressure, some of the pyritic mercury may also be removed.

\section{Lignite-Fired Power Plants}

Mercury control testing was conducted at selected plants based on the lignite characteristics and characteristics of Air Pollution Control Devices (APCDs). Options for mercury control in existing coal-fired power plants consisted mainly of the enhancement of existing air pollution control systems and the addition of new multipollutant control options such

as FFs and scrubbers. Enhancement of existing APCDs includes sorbent injection with and without SEAs upstream of existing particulate control systems and mercury oxidation upstream of wet and dry scrubbers. 
The use of sorbent and/or ACI as a means of removing mercury from lignite combustion flue gas is widely accepted as the most developed and commercially viable method. Application of sorbent injection in coal-fired utility boilers is very challenging because of lower concentrations of mercury and the range of mercury forms in coal combustion flue gases. Their effectiveness depends on coal type and power plant configuration.

\section{Mercury Transformations and Speciation}

Mercury transformations and speciation are keys to identifying, developing, and utilizing effective mercury control technologies. The chemical reactions of mercury in the flue gas with other gaseous components and entrained-ash species impact the mercury speciation in the flue and effectiveness of the control technology. The mechanisms involve both homogeneous and heterogeneous reactions of mercury in flue gas, entrained-ash particles, and sorbents.

The unique composition of lignite coals has an equally unique influence on mercury transformation and speciation. Low-chlorine $(<50 \mathrm{ppm})$ coal combustion flue gases, which are typical of low-rank coals, contain predominantly $\mathrm{Hg}^{0}$, which is substantially more difficult to remove than $\mathrm{Hg}^{2+}$. The injection of chemicals and finely powdered sorbent injection upstream of a particulate collection device has the potential to capture both $\mathrm{Hg}^{0}$ and $\mathrm{Hg}^{2+}$ present in the flue gas. The effectiveness of halogenated carbons for mercury capture has been known since 1934. Originally, the model for this type of sorbent was that the halogens on the carbon were responsible for reactions with the $\mathrm{Hg}^{0}$, but a considerable amount of chemical evidence showed that the halogens impregnated into carbon react with the carbon and are strongly bound to the carbon. So it is more likely that the halogens promote the reactivity of the carbon, as we have demonstrated for $\mathrm{HCl}$, rather than react as such with the $\mathrm{Hg}^{0}$. More work is needed and ongoing to clarify this mechanism with the halogenated carbons. Nonetheless, owing to the high reactivity of the halogenated carbons through the use of SEAs and direct enhancement, full-scale testing of these sorbents has been conducted.

\section{Mercury Measurement}

Mercury CEMs are necessary and useful tools for measuring mercury for both research and compliance applications, and a variety of instruments are available, each with unique advantages and drawbacks. Measuring mercury in a flue gas stream generated by coal combustion is much more challenging than measuring from other sources. Sources like incinerators typically have more pollution control equipment such as scrubbers in conjunction with FFs and sorbent beds, which all help to clean up the flue gas before it reaches a mercury measurement system. However, development is ongoing to address the challenges of providing long-term operation for flue gas monitoring with a minimal amount of maintenance. All of the analyzers mentioned will measure mercury in a relatively clean sample gas stream. The main challenge facing mercury CEM manufacturers is providing a "clean" sample gas to the mercury analyzer. The sample conditioning methods currently available are listed below:

- Wet Chemistry - These systems provide speciated mercury data by using wet-chemistry methods to either remove or reduce oxidized mercury from the sample gas as well as remove interferant gases from the sample gas stream. To date, these have been the most 
frequently used systems for research, and a great deal of data has been collected while using them. The reliability of these systems has been improved through several design iterations, but they still require more maintenance than is acceptable for long-term monitoring. Because these systems are wet-chemistry-based, they require large amounts of chemicals and generate a large amount of waste (up to 8 liters a day). The wetchemistry systems have worked well in plants burning either lignite or subbituminous coal. However, in plants burning bituminous coal with high sulfur and chlorine, there have been problems with the chemistry of the system. Some plants with high $\mathrm{SO}_{2}$ also generate high $\mathrm{SO}_{3}$ concentrations. The $\mathrm{SO}_{3}$ can pass through the wet-chemistry portion of the system as an aerosol and deposit on backup filters and sample lines. This can cause problems with mercury capture and changes to speciation. The wet-chemistry systems can be used with any type of mercury analyzer.

- Thermal Catalytic Reduction - These systems can provide speciated mercury data. The oxidized forms of mercury are reduced to elemental mercury across a catalyst bed. A dry sorbent or wet-chemistry system may be used to remove oxidized mercury from the sample gas stream. These systems may include additional wet-chemistry systems for removing interferants from the gas stream before sending the gas to the analyzer. The volume of wet chemicals consumed in these systems is much smaller than the all-wet systems (on the order of a liter a week). Limited long-term data have been generated using these systems. However, there appears to be problems with the life of the catalysts, particularly in high-acid-gas situations. The catalysts are expensive and may need frequent regeneration and/or replacement. The thermal catalytic systems have yet to demonstrate long-term reliability. It is most likely that not all of the interferants and interactions with different flue gas components have been identified. Thermal catalytic reduction is best used with the cold-vapor atomic absorption spectroscopy (CVAAS) analyzers because the interferant gases for cold-vapor atomic fluorescence spectroscopy (CVAFS) are not necessarily removed.

- Dilution and Thermal Catalytic Reduction - This is a relatively new method for conditioning the sample gas for mercury analysis. These systems dilute the sample gas at or near the probe before sending it to a sample conditioner. The theory is that the diluted sample is easier to transport and condition. The lower concentrations of interferant gases are also less likely to poison the catalyst used for reducing oxidized mercury to elemental mercury. Speciating the mercury is accomplished by scrubbing the oxidized mercury from the sample gas with a small amount of deionized water or a dry trap. Again, it is most likely that not all of the interferants and interactions with different flue gas components have been identified. Because of dilution and the resulting low mercury concentrations, a CVAFS analyzer must be used. These systems are the latest iteration of conditioning systems, and not much data have been generated with them, but they have the potential to be very reliable with low maintenance requirements.

At this time, there does not appear to be one instrument or measurement technology that will work best in all applications. The most advanced systems are those that integrate all of the 
components necessary to measure accurately and reliably mercury emissions from a utility boiler. These components include:

- Particulate Removal System - It must continuously remove particulate matter before it can interact with the sample gas.

- Sample Transport - It must be integrated with the sample probe.

- Sample Conditioning System - It must provide "clean," dry sample gas to the mercury analyzer.

- Mercury Analyzer.

- Calibration/Spiking System - It offers easy, preferably automatic calibration checks. Dynamic spiking of elemental mercury into the flue gas matrix at the probe is a plus.

\section{Mercury Control Options}

Pilot-scale and slipstream testing activities were aimed at developing and evaluating advanced and innovative concepts for controlling mercury emissions from North Dakota lignitefired power plants by $50 \%-90 \%$ at costs of one-half to three-quarters of current estimated costs. The specific objectives were focused on determining the feasibility of the following technologies: mercury oxidation for increased mercury capture in wet and dry scrubbers, incorporation of additives and technologies that enhance mercury sorbent effectiveness in ESPs and baghouses, the use of amended silicates in lignite-derived flue gases for mercury capture, and the use of mercury adsorbents within a baghouse. The scientific approach to solving the problems associated with controlling mercury emissions from lignite-fired power plants involves conducting testing of the following processes and technologies that have shown promise on a bench, pilot, or field scale: 1) ACI upstream of an ESP combined with sorbent enhancement, 2) mercury oxidation and control using wet and dry scrubbers, 3) enhanced oxidation at a full-scale power plant using tire-derived fuel (TDF) and oxidizing catalysts, and 4) testing of mercury control technologies in the Advanced Hybrid ${ }^{\mathrm{TM}}$ filter insert.

The applicability of potential mercury sorbents (DARCO ${ }^{\circledR}$ FGD, HCl-treated FGD, and EERC-treated FGD), $\mathrm{Hg}^{0}$ oxidation, and SEAs $\left(\mathrm{NaCl}, \mathrm{CaCl}_{2}\right.$, and SEA2) to improve the $\mathrm{Hg}(\mathrm{g})$ removal efficiency of ESP, SD/FF, and ESP/Advanced Hybrid ${ }^{\mathrm{TM}}$ filter pollution control systems were evaluated using a pilot-scale pulverized coal-fired unit. Test results for the ESP, SD/FF, and ESP/Advanced Hybrid ${ }^{\mathrm{TM}}$ filter are summarized in Tables 2 to 4, respectively. The sorbents and additives are generally ranked in descending order of $\mathrm{Hg}(\mathrm{g})$ removal effectiveness.

Most of the mercury sorbents and coal additives, and combinations thereof, enhanced the $\mathrm{Hg}(\mathrm{g})$ removal performance of the ESP relative to the baseline mercury control strategy of injecting DARCO ${ }^{\circledR}$ FGD alone. HCl-treated FGD combined with the coal additive $\mathrm{NaCl}$ provided higher $\mathrm{Hg}(\mathrm{g})$ ESP removal efficiencies than the DARCO ${ }^{\circledR}$ FGD alone. EERC-treated 
Table 2. Average ESP Hg(g) Removal Efficiencies for Sorbents and/or Additives, \%

\begin{tabular}{|c|c|c|c|c|c|c|c|c|c|c|}
\hline \multirow[b]{2}{*}{ Sorbent and/or Additive } & \multicolumn{10}{|c|}{ Injection or Addition Rate, lb/Macf } \\
\hline & 1 & 2 & 3 & 4 & 5 & 7 & 9 & 11 & 15 & 18 \\
\hline HCl-Treated FGD and NaCl@ 11.0 lb/Macf & & & & & 90 & & & & & \\
\hline HCl-Treated FGD and $\mathrm{NaCl} @ 7.34$ lb/Macf & & & 72 & & 85 & & & & & \\
\hline EERC-Treated FGD and SEA2 @ 1.84 lb/Macf & & & 82 & & & & & & & \\
\hline SEA2 and DARCO ${ }^{\circledR}$ FGD @ 2.57 lb/Macf & & 76 & & & & & & & & \\
\hline EERC-Treated FGD & & 69 & 77 & & & & & & & \\
\hline DARCO ${ }^{\circledR}$ FGD and NaCl@ 7.34 lb/Macf & & & 54 & & 75 & & & & & \\
\hline $\mathrm{NaCl}$ and DARCO ${ }^{\circledR}$ FGD @ 4.59 lb/Macf & & & & 68 & & 75 & & 80 & 73 & \\
\hline $\mathrm{CaCl}_{2}$ and DARCO ${ }^{\circledR} \mathrm{FGD} @ 4.59 \mathrm{lb} / \mathrm{Macf}$ & & & & & & & & 73 & & \\
\hline $\mathrm{NaCl}$ and DARCO ${ }^{\circledR}$ FGD @ 2.57 lb/Macf & & & & & & 53 & & 68 & & \\
\hline SEA2 & & 33 & & & & 64 & & & & \\
\hline DARCO $^{\circledR}$ FGD & & & & & 52 & & 59 & & & 67 \\
\hline $\mathrm{NaCl}$ & & & & 17 & & 24 & & 46 & 46 & \\
\hline $\mathrm{CaCl}_{2}$ & & & & & & & & 44 & & \\
\hline
\end{tabular}

Table 3. Average ( $\pm 95 \%$ confidence limit) SD/FF Hg(g) Removal Efficiencies for Sorbents and/or Additives, \%

\begin{tabular}{|c|c|c|c|c|}
\hline \multirow[b]{2}{*}{ Sorbent and/or Additive } & \multicolumn{4}{|c|}{ Injection or Addition Rate, lb/Macf } \\
\hline & 1.84 & 3.67 & 7.35 & 11.0 \\
\hline SEA2 and DARCO ${ }^{\circledR}$ FGD @ 1.84 lb/Macf & $94.6 \pm 0.9$ & $94.3 \pm 2.6$ & & \\
\hline EERC-Treated FGD & $85.1 \pm 1.9$ & $94.4 \pm 1.3$ & $98.3 \pm \mathrm{NA}^{1}$ & \\
\hline SEA2 & $53.7 \pm 5.3$ & $81.8 \pm 1.2$ & & \\
\hline $\mathrm{NaCl}$ and DARCO ${ }^{\circledR}$ FGD @ 3.67 lb/Macf & & $66.6 \pm 2.4$ & $82.6 \pm 2.4$ & $91.2 \pm 0.5$ \\
\hline $\mathrm{CaCl}_{2}$ and DARCO ${ }^{\circledR} \mathrm{FGD} @ 3.67 \mathrm{lb} / \mathrm{Macf}$ & & $74.2 \pm 1.7$ & $78.4 \pm 2.1$ & $76.5 \pm 4.5$ \\
\hline Amended Silicate ${ }^{\mathrm{TM}}$ & & & $74.9 \pm 9.1$ & \\
\hline $\mathrm{DARCO}^{\circledR} \mathrm{FGD}$ & $36.5 \pm 2.5$ & $43.2 \pm 1.3$ & $55.5 \pm 2.2$ & $59.3 \pm 3.4$ \\
\hline $\mathrm{NaCl}$ & & $23.5 \pm 3.6$ & $31.5 \pm 2.3$ & $27.8 \pm 0.4$ \\
\hline $\mathrm{CaCl}_{2}$ & & $9.5 \pm 0.8$ & $24.2 \pm 1.4$ & $20.0 \pm 2.8$ \\
\hline
\end{tabular}

${ }^{1}$ Not applicable because an insufficient number of analyses were made to calculate a value. 
Table 4. Average ESP/Advanced Hybrid ${ }^{\mathrm{TM}}$ Filter Hg(g) Removal Efficiencies for Sorbents and/or Additives, \%

Injection or Addition Rate, lb/Macf

\begin{tabular}{|c|c|c|c|c|c|c|c|c|}
\hline Sorbent and/or Additive & 1 & 2 & 3 & 4 & 5 & 7 & 8 & 11 \\
\hline $\begin{array}{l}\text { DARCO }^{\mathbb{B}} \text { FGD (batch addition) and } \mathrm{NaCl} @ \text {, } \\
7.34 \mathrm{lb} / \mathrm{Macf}\end{array}$ & 73 & & & & & & & \\
\hline DARCO $^{\circledR}$ FGD and $\mathrm{NaCl} @ 7.34$ lb/Macf & & & 74 & & & & & \\
\hline DARCO $^{\circledR}$ FGD (batch addition) & 32 & 47 & & 87 & & & 94 & \\
\hline DARCO $^{\circledR}$ FGD & 43 & 56 & & 59 & & & 72 & \\
\hline SEA2 & & 50 & & & & 77 & & \\
\hline $\operatorname{DARCO}^{\circledR} \mathrm{FGD}\left(204^{\circ} \mathrm{C}, 400^{\circ} \mathrm{F}\right)$ & 42 & 47 & & & 54 & & & \\
\hline DARCO ${ }^{\circledR} \mathrm{FGD}$ (batch addition, $204^{\circ} \mathrm{C}, 400^{\circ} \mathrm{F}$ ) & & 46 & & & & & & \\
\hline Regenerated FGD & & 48 & & & & & & \\
\hline $\mathrm{NaCl}$ & & & & 12 & & 30 & & 48 \\
\hline
\end{tabular}

FGD injection alone and SEA2 addition combined with EERC-treated FGD or DARCO ${ }^{\circledR}$ FGD injection at relatively low rates $(2-3 \mathrm{lb} / \mathrm{Macf})$ provided an ESP $\mathrm{Hg}(\mathrm{g})$ removal efficiency of about $80 \%$.

The SEA2 additive, alone or in combination with DARCO ${ }^{\circledR}$ FGD injection, and the EERCtreated FGD effectively enhanced $\mathrm{SD} / \mathrm{FF} \mathrm{Hg}(\mathrm{g})$ removal performance. Combinations of DARCO ${ }^{\circledR}$ FGD injection and $\mathrm{NaCl}$ and $\mathrm{CaCl}_{2}$ additions into the Center, North Dakota, lignite combustion flue gas and coal, respectively, were also effective but required higher input rates to achieve $>80 \% \mathrm{Hg}(\mathrm{g})$ removal efficiencies.

\section{Mercury Control Testing Results}

\section{Leland Olds Station (LOS) - Basin Electric Power Cooperative - ESP Only \\ Parametric - Lignite}

- Maximum mercury capture with powdered activated carbon (PAC) only was 70\% at 20 lb/Macf.

- The addition of SEA improved mercury capture compared to PAC only.

- The best mercury capture of $87 \%$ was obtained with the parametric conditions of $3.7 \mathrm{lb} / \mathrm{Macf}$ SEA and $10 \mathrm{lb} /$ Macf PAC. 
- Parametric data were used to set the monthlong test condition at $3.7 \mathrm{lb} /$ Macf SEA (500 ppm Cl in the coal) and $3 \mathrm{lb} / \mathrm{Macf}$ PAC.

Parametric - Blend Lignite and Subbituminous

- The best mercury capture of $82 \%$ was obtained with the parametric conditions of $3.7 \mathrm{lb} / \mathrm{Macf}$ SEA and $5 \mathrm{lb} /$ Macf PAC.

- Capture of mercury was similar to that with $100 \%$ lignite.

\section{Monthlong}

- The average SEA rate for the monthlong test was $2.9 \mathrm{lb} / \mathrm{Macf}$.

- The average PAC rate for the monthlong test was $2.7 \mathrm{lb} /$ Macf.

- Carbon in the ESP ash increased from $1.78 \pm 0.41 \%$ to $2.04 \pm 1.21 \%$ during monthlong PAC injection. The expected monthlong carbon concentration of $2.16 \%$ is within this statistical range.

- Particulate loading at the ESP outlet increased from $0.0088 \pm 0.0007$ to $0.0170 \pm 0.0305$ grains/dscf.

- The monthlong average opacity of $6.18 \pm 1.90$ did not exceed the EPA compliance limit of $20 \%$.

- Average mercury capture for the monthlong test was $58 \%$.

- The mercury capture varied significantly with coal mercury concentrations.

\section{Coal Creek Station - Great River Energy - ESP and WFGD}

\section{Baseline and Parametric}

- Average baseline removal level for mercury was $7 \%$, with a range of $5 \%-20 \%$.

- DARCO ${ }^{\circledR}$ FGD AC, injection rates of 1 and $3 \mathrm{lb} /$ Macf, average mercury removal was $46 \%$ and $58 \%$, respectively.

- DARCO $^{\circledR}$ FGD injection rate $>5 \mathrm{lb} /$ Macf resulted in a mercury removal rate of $70 \%$. However, injection rates of $10 \mathrm{lb} / \mathrm{Macf}$ and higher did not appear to increase mercury removal.

\section{Balance of Plant Issues}

- Because of the short duration of these tests, balance-of-plant (BOP) issues could not be evaluated practically. 
- During ACI tests with only $25 \%$ of the flue gas being treated, a $10 \%$ to $30 \%$ increase in rapping spike opacity was observed.

- Carbon was evident on the surface of the scrubber slurry during ACI tests, indicating that some AC was passing through the ESP.

- Particulate sampling at the outlet of the ESP during baseline and ACI tests showed a 100\% increase in the outlet mass loading when carbon was injected.

- An electrical short was experienced in the fifth field of the ESP after a period of ACI was completed.

- Loss on ignition (LOI) analyses of fly ash samples collected from the fourth field of the ESP during baseline and ACI tests showed that LOI values increased from 0.14 to $3.79 \mathrm{wt} \%$ as a result of ACI.

\section{Stanton Station - Great River Energy - SDA-FF}

\section{Parametric}

- Unit 10 parametric testing included evaluation of six sorbents: 1) DARCO ${ }^{\circledR}$ FGD, 2) CB 200xF BS IAC (iodated coconut shell), 3) FGD-E1 (chemically treated), 4) FGD-E3 (halogenated), 5) 208CP BS SAC (superactivated coconut shell), and 6) ST BAC (brominated).

- Results from the parametric testing demonstrated that the NORIT DARCO ${ }^{\circledR}$ FGD AC achieved $75 \%$ mercury removal at an injection rate of $6.0 \mathrm{lb} / \mathrm{Macf}$.

- Barnebey Sutcliffe 208CP BS SAC achieved almost 60\% mercury removal at an injection rate of $1.5 \mathrm{lb} / \mathrm{Macf}$.

- Chemically treated carbons performed significantly better than the nonchemically treated carbons. Specifically, at an injection rate of $1.0 \mathrm{lb} / \mathrm{Macf}$, both the DARCO ${ }^{\circledR} \mathrm{Hg}-\mathrm{LH}$ and Sorbent Technologies ST BAC demonstrated mercury removal rates of $>85 \%$. At an ACI rate of $1.5 \mathrm{lb} /$ Macf, mercury removal rates of $>90 \%$ were observed for the FGD-E3 and ST BAC materials.

- The Barnebey Sutcliffe CB 200xF BS IAC AC did not produce 90+\% mercury removal, possibly because of particle size.

\section{Extended Testing}

- NORIT FGD-E3 AC was injected for 24 days at a rate of $1.0 \mathrm{lb} / \mathrm{Macf}$ to achieve $65 \%-75 \%$ mercury removal. 
- The lower mercury removal rate observed during the extended testing is believed to be related to the higher sulfur concentration when compared to parametric tests. Based on the testing completed on Unit 10, neither the sorbent injection rate nor the sorbent type affected the FF cleaning frequency. Also, no noticeable differences were observed in the operation of the spray dryer system during the baseline tests or the ACI test.

\section{Poplar River Power Station - SaskPower - ESP-FF}

\section{Screening Tests}

- Screening tests evaluated mercury capture for nine AC sorbents. The results showed that the top four performers (NORIT Hg LH, EERC C3PO, NORIT Hg, and Luscar 4) achieved greater than $90 \%$ removal at an ACI rate of approximately $2 \mathrm{lb} /$ Macf.

- Within the group of sorbents tested at the emissions control research facility (ECRF), the treated ACs offered only marginal benefit compared to the untreated. Temperatures from approximately $200^{\circ}-350^{\circ} \mathrm{F}$ were tested, and no impact on mercury capture for the four sorbents tested was found.

\section{Parametric Tests}

- Effects of air-to-cloth $(\mathrm{A} / \mathrm{C})$ ratio on mercury adsorption by the various $\mathrm{AC}$ sorbents. Little effect on mercury capture was shown as a result of the A/C ratio tested for Luscar 2, Luscar 4, and NORIT Hg from 2 to $8 \mathrm{ft} / \mathrm{min}$. The following is a summary of the results:

- A/C had little, if any, effect on mercury capture.

- $\mathrm{A} / \mathrm{C}$ significantly impacts baghouse operation, notably $\Delta \mathrm{P}$ and required cleaning frequency.

- Effects of ash loading on mercury capture were also investigated for three different AC sorbent materials with no significant impacts found. Batch injection of $\mathrm{AC}$ for selected carbons does not appear to provide a benefit over continuous AC feed.

\section{Long-Term Testing Program 1 (LT1)} follows:

LT1 was conducted using Luscar 4 and NORIT Hg. The results are summarized as

- Consistent mercury capture with an average of $83 \%$ at a PAC injection rate of $2.2 \mathrm{lb} / \mathrm{Macf}$.

- Pressure drop issues resulted in increased cleaning frequency.

- FF operations are not sustainable at these conditions, indicating lower $\mathrm{A} / \mathrm{C}$ required for stable operation. 
The second long-term test was conducted using lower ash loading, relative to LT1. This ash loading is closer to that found in North Dakota plants combusting lignite. Because different ash loadings affect the $\Delta \mathrm{P}$ and/or cleaning frequency of Fabric Filter 2 (FF2), these long-term tests were important as inputs into the economic evaluation, identifying optimal trade-offs between capital and operating costs when using sorbents for this coal.

The LT2 results are summarized as follows:

- Average mercury capture of $82 \%$ at a PAC injection rate of $2.5 \mathrm{lb} /$ Macf.

- Increased variability due to changing of sorbent and inconsistency in feed rate.

- No pressure drop issues encountered.

- Sustainable FF operations at these conditions.

- $\Delta \mathrm{P}$ settling out at approximately 6 in. water column (W.C.)

Following the formal end of the second long-term test, additional tests with higher $\mathrm{A} / \mathrm{C}$ ratios were conducted by increasing the flue gas flow rate through the ECRF to $8000 \mathrm{acfm}(\mathrm{A} / \mathrm{C}=8 \mathrm{ft} / \mathrm{min})$. The results of this test showed that this high $\mathrm{A} / \mathrm{C}$ cannot be sustained for long periods of time without affecting the cleanability of the FF elements. At the higher $\mathrm{A} / \mathrm{C}$ ratios, the maximum allowable $\Delta \mathrm{P}$ was reached within 3 days of the start of the test.

The additional high $\mathrm{A} / \mathrm{C}$ testing results are summarized as follows:

- Mercury capture was consistent with an average of $79 \%$ at a PAC injection rate of $2.5 \mathrm{lb} / \mathrm{Macf}$.

- Maximum pressure drop was reached in 3 days.

- FF operations were not sustainable at these conditions.

Long-Term Testing Program 3 (LT3)

The third long-term test was conducted using high-permeability bags to determine if the pressure drop problems experienced during LT1 under high-ash-load conditions could be alleviated.

The additional LT3 with high permeability bags found the following:

- Average mercury capture of $82 \%$ at a PAC injection rate of $2.8 \mathrm{lb} /$ Macf.

- Increased variability because of inconsistency in feed rate.

- No pressure drop issues were encountered.

- The $\Delta \mathrm{P}$ settled out at less than 1 in. W.C. 


\section{Antelope Valley Station - Basin Electric Power Cooperative - SDA-FF}

\section{Baseline Testing}

- The average mercury concentration measured during baseline conditions was $9.3 \pm 0.6 \mu \mathrm{g} / \mathrm{dNm}^{3}$.

- The primary mercury species measured in the flue gas at AVS was $\mathrm{Hg}^{0}$ with a baseline average of $8.8 \mu \mathrm{g} / \mathrm{dNm}^{3}$.

- Baseline testing showed no native capture of mercury across the SDA-FF device.

- The halogen concentrations measured at baseline conditions were at levels below the detection limit of the method.

- Carbon concentrations measured in the FF and SDA ash were low at 0.21 and $0.25 \mathrm{wt} \%$, respectively.

\section{Parametric Testing}

- Injection of SEA1 and $2 \mathrm{lb} / \mathrm{Macf}$ of PAC yielded a maximum mercury removal efficiency of $75 \%$.

- Injection of SEA2 and $2 \mathrm{lb} / \mathrm{Macf}$ of PAC yielded a maximum mercury removal efficiency of $90 \%$.

- PAC injection alone at $1.0 \mathrm{lb} /$ Macf provided a mercury removal efficiency of 55\%.

- The monthlong control options chosen were PAC and SEA2 feed rates of nominally 1.0 and $0.033 \mathrm{lb} /$ Macf, respectively.

- SEA2 (Method 2) tested during parametric testing proved to be very promising, providing for mercury removal efficiencies $>90 \%$ at lower injection rates than SEA2.

\section{Monthlong Testing}

- The average monthlong mercury removal efficiency was $91.6 \pm 0.30 \%$ at a $95 \%$ confidence interval.

- The carbon concentration increased from $0.21 \mathrm{wt} \%$ during baseline to $0.31 \mathrm{wt} \%$ during the PAC injection period for monthlong testing. This was found to be statistically significant, and calculations showed an expected increase of $\sim 0.09 \mathrm{wt} \%$ from the addition of PAC. 
- Method 26 analysis showed that the addition of SEA2 had a negligible effect on the halogen concentration in the flue gas.

- Corrosion probe analysis showed a negligible effect from the injection of SEA2.

\section{Milton R. Young Station - Minnkota Power Cooperative - ESP-Wet FGD}

\section{Baseline}

- Mercury concentrations at the ESP and wet FGD inlets varied from about 12 to $16 \mu \mathrm{g} / \mathrm{dNm}^{3}$, whereas at the stack, concentrations were consistently at about $13 \mu \mathrm{g} / \mathrm{dNm}^{3}$.

- The ESP and WFGD were very inefficient at removing mercury primarily because $\mathrm{Hg}^{0}$ was dominant.

\section{Parametric}

- Calcium chloride $\left(\mathrm{CaCl}_{2}\right)$, magnesium chloride $\left(\mathrm{MgCl}_{2}\right)$, and a proprietary sorbent enhancement additive, hereafter referred to as SEA2, were added to the coal feed to enhance mercury capture in the ESP and/or WFGD.

- PAC was injected upstream of the ESP.

- $\mathrm{MgCl}_{2}$ and $\mathrm{CaCl}_{2}$ were relatively ineffective in promoting $\mathrm{Hg}^{0}$ oxidation and capture in the ESP-WFGD.

- Relatively low additions of SEA2, however, significantly improved the mercury removal efficiency of the ESP-WFGD, although the goal of 55\% mercury removal was not achieved using as much as 75 ppm SEA2 (dry coal basis).

- Most of the mercury removal occurred in the ESP, suggesting that the SEA2 addition promoted the conversion of $\mathrm{Hg}^{0}$ to particulate-bound mercury.

\section{Monthlong Testing}

- SEA2 addition (50-100 ppm, dry coal basis) combined with $0.15 \mathrm{lb} / \mathrm{Macf}$ PAC injection was performed for a month during which mercury removals ranged from $50 \%$ to $65 \%$.

\section{Monticello Station - Texas Utilities Company - ESP-FGD}

\section{Baseline and Parametric}

- Two mercury oxidation agents were tested: $\mathrm{CaCl}_{2}$ and $\mathrm{CaBr}_{2}$. The $\mathrm{CaCl}_{2}$ was injected at rates ranging from 400 to $800 \mathrm{ppm}$ of the active reagent (AR) in the coal. The $\mathrm{CaBr}_{2}$ was injected at rates ranging from 12 to $200 \mathrm{ppm} \mathrm{AR}$ in the coal. Based on the results, $\mathrm{CaBr}_{2}$ was selected for the long-term tests. 


\section{Extended Period Testing}

- Two 2-week periods of $\mathrm{CaBr}_{2}$ injection followed. Baseline measurements were made prior to the start of each long-term period. In the first 2-week period (November 5-18, 2005), the target injection rate was $50 \mathrm{ppm} \mathrm{Br}$ in the coal; for the second 2-week period (December 2$14,2005)$, the primary target injection rate was $100 \mathrm{ppm} \mathrm{Br}$ in the coal.

- Mercury removal rate across the APCD ranged from $44 \%$ to $89 \%$ during the 2 -week-long tests depending on the $\mathrm{Br}$ injection rate.

\section{Big Brown Station - Texas Utilities Company - ESP-FF}

\section{Baseline Testing}

- Mercury removal across the baghouse appears to be minimal.

\section{Parametric Testing}

- In general, mercury removals observed during parametric testing were better than anticipated, with smaller amounts of sorbents being required.

- Both the AC-SEA4 and enhanced AC options performed better than AC-only injection. Short-term tests showed that greater than $70 \%$ could be achieved at injection rates of $2 \mathrm{lb} /$ Macf or lower.

- Short-term tests identified that injection of sorbents at rates greater than $2 \mathrm{lb} / \mathrm{Macf}$ resulted in significantly increased $\Delta \mathrm{P}$ across the FF.

\section{Monthlong Testing}

- An overall average mercury removal efficiency of greater than $70 \%$ (preliminary) was achieved for the monthlong testing using enhanced AC; this exceeded the proposed target removal of $55 \%$.

- Mercury removal efficiencies were similar for the 70\% lignite- $-30 \%$ PRB and $100 \%$ PRB with enhanced AC; however, mercury emissions were much lower with the 100\% PRB primarily because of the lower mercury content in coal.

- BOP effects were observed throughout the tests, specifically increasing $\Delta \mathrm{P}$ buildup across the FF, which may prove to be the limiting factor for applying sorbent injection at Big Brown. Further investigation into these effects is critical and ongoing. Results will be reported later. 


\section{Leland Olds Unit 1 - Basin Electric - ESP}

Field Demonstration of the ALSTOM Power, Inc., Mer-Cure ${ }^{\mathrm{TM}}$ System

The following summarizes LOS1 test campaign:

- The long-term performance data show that at the air heater inlet, mercury was mostly $\mathrm{Hg}^{0}$ ( $97 \%$ of total gaseous mercury); the mercury further oxidized at the backpass to give a total of $77 \%$ of the mercury as elemental at the ESP outlet. During injection of the sorbent, the elemental form of the total gaseous mercury at the ESP outlet further decreased to $63 \%$, demonstrating the role of the sorbent as an oxidation catalyst. For boilers with scrubbers, most of this oxidized mercury at the ESP outlet will be further removed by the scrubbers. As a result, even higher removal efficiency will be achieved.

- The long-term performance of Mer-Cure ${ }^{\mathrm{TM}}$ system at Basin Electric Power Cooperative's LOS1, as measured by both the Ontario Hydro method and CMMs, shows that at an injection rate of $1.5 \mathrm{lb} / \mathrm{Macf}, 90 \%$ removal of total gaseous mercury has been achieved with the Mer-Cure ${ }^{\mathrm{TM}}$ system.

- The effect of the Mer-Cure ${ }^{\mathrm{TM}}$ system processor on sorbent performance improvement has been demonstrated. For a given mercury removal target, the sorbent consumption rate for the Mer-Cure ${ }^{\mathrm{TM}}$ system with its processor turned on was only half of that with it turned off.

\section{Mercury in Coal Combustion By-Products}

The data available on CCB mercury content and stability are limited because demonstration of mercury control technologies has only recently been initiated at large-scale lignite-fired power plants. The data available on fly ash and FGD materials generated at fullscale coal-fired power plants without mercury emission controls in place indicate relatively low levels of mercury ranging from $<0.01$ to $2.41 \mathrm{ppm}$. The mercury in fly ash and FGD collected during tests of mercury control technologies has had levels as high as 120 ppm reported; however, of 21 samples collected from mercury control demonstrations, only six had mercury concentrations greater than those noted for samples from systems without mercury control. These data represent a very limited number of samples, types of mercury control, and combustion systems.

Existing data indicate that the stability of mercury on fly ash and FGD material is similar for samples collected at sites without mercury controls and during tests of mercury control technologies.

Based on the results of the laboratory experiments conducted, the following conclusions are made regarding the impact ACI will have on CCBs generated from Fort Union lignite coals:

- ACI will increase carbon and mercury content in fly ash. 
- Total selenium concentration increases with ACI in low-ash-loading samples. The EERC believes that the selenium is sorbed onto the carbon; therefore, the total selenium concentration in high-ash-loading samples is similar to the baseline sample.

- Although the samples had higher total mercury concentration, it is extremely unlikely that mercury will leach from fly ash. This confirms results from other studies. It is not expected that regulatory changes will occur for the management of CCBs based on the potential for mercury to leach from CCBs.

- Long-term leaching is required for Fort Union lignite fly ashes, especially for elements such as arsenic, selenium, boron, and chromium.

- $\mathrm{ACI}$ increases the temperature at which mercury is released in elevated-temperature applications, indicating that $\mathrm{AC}$ has a tighter bond with mercury. Unless fly ash is going to be used in cement production (at approximately $1100^{\circ} \mathrm{C}$ ), there is little concern the mercury will be released from fly ash at temperatures achieved in typical beneficial use applications such as concrete.

- Ambient-temperature tests show no adverse impact on mercury loading to the environment. For those disposing of their CCBs in landfill or surface impoundments, the likelihood for mercury to be released into the air is extremely low.

- CCB soil test observations indicate the potential for increased elemental mercury and organomercury release with soil addition. Mercury release from fly ash is expected to be higher when fly ash is mixed with soil in beneficial use applications such as soil amendments, but the amount of mercury released is low and not expected to be a concern.

- Foam index testing shows that the fly ash with ACI is unlikely to be used in concrete applications with the air-entraining admixture (AEA) tested. Other AEAs or beneficiation technologies may make the fly ash suitable for use in concrete.

- Expansion testing indicates swell potential, as is typical for other high-calcium fly ashes.

\section{Future Directions}

Even though a significant effort has been conducted on mercury measurement and control technologies, uncertainties remain which can impact the reliability of the mercury control technology and the power plant. Electricity is the most critical infrastructure system in the United States, and it requires robust, well-tested, and reliable processes and equipment. Mercury emission control technologies must follow a universal product development path that includes long-term testing on a range of power plant configurations and fuel combinations to identify the unintended consequences of the technology. One of the key issues associated with mercury control is that there is no one-size-fits-all solution, even within the same fuel rank. 
For a technology to be considered commercially available, the following criteria must be met:

- Reliable: the process and effects on balance-of-power plant operations are known.

- Efficient: the mercury removal consistently meets the limits set under varying plant operational parameters and fuel changes.

- Environmentally benign: the mercury control process does not create additional, unintended environmental issues.

- Supply availability: there are sufficient resources to allow the industry as a whole to install and operate.

The following testing needs to be conducted in order to minimize uncertainties that include the following:

- Long-term testing for a minimum of 1 year to answer questions about the following:

- Ability to remove mercury consistently during normal plant operations and under normal operating conditions.

- Corrosion of system components when adding chemical oxidation agents or enhanced carbons.

- Potential release of additives from sorbents or ash because of prolonged reaction with flue gases.

- Impact on ESP performance under long-term operation.

- Impact on baghouse operations, specifically bag life, because of increased cleaning cycles and/or pressure drop.

- Stability of carbon collected in the baghouse to determine the potential for hot spots and fires.

- Reemission of mercury in scrubber applications.

- Impact of $\mathrm{NO}_{\mathrm{x}}$ control strategies on mercury control.

- Novel methods needed for lignite because of ash-blinding issues associated with lignite coals.

- Ash utilization

- Concrete-friendly sorbents for mercury control. 
- Potential for the release of organo- and elemental mercury from ash.

- Compliance monitoring

- Reliability, accuracy, and maintainability of mercury-specific CEMs for the range of flue gas compositions is required.

- Validation and testing of dry sorbent extractive methods.

\section{REFERENCES}

1. Fitzgerald, W.F.; Engstrom, D.R.; Mason, R.P.; Nater, E.A. The Case for Atmospheric Mercury Contamination in Remote Areas. Environ. Sci. Technol. 1998, 32 (1), 1-7.

2. Fitzgerald, W.F.; Clarkson, T.W. Mercury and Monomethylmercury: Present and Future Concerns. Envir. Health Perspec. 1991, 96, 159-166.

3. Mercury Study Report to Congress, Volume I: Executive Summary, EPA-452/R-97-003; Volume II: An Inventory of Anthropogenic Mercury Emissions in the United States, EPA452/R-97-004; Volume II: Fate and Transport of Mercury in the Environment, EPA452/R-97-005; Volume IV: An Assessment of Exposure to Mercury in the United States, EPA-452/R-97-006; Volume V: Health Effects of Mercury and Mercury Compounds, EPA452/R-97-007; Volume VI: An Ecological Assessment for Anthropogenic Mercury Emissions in the United States, EPA-452/R-97-008; Volume VII: Characterization of Human Health and Wildlife Risks from Mercury Exposure in the United States, EPA452/R-97-009; Volume VIII: An Evaluation of Mercury Control Technologies and Costs, EPA-452/R-97-010, U.S. Environmental Protection Agency Office of Air Quality Planning \& Standards and Office of Research and Development, Dec 1997.

4. McMillan, M.; Arnold, S. Mining Existing Data to Assess Mercury Impacts. In Proceedings of the Conference on Air Quality II: Mercury, Trace Elements, and PM; September 19-21, 2000, McLean, Virginia, Paper A1-2.

5. Jacobs, H.L.; Kahn, H.D.; Stralka, K.A.; Phan, D.B. Estimates of per Capita Fish Consumption in the U.S. Based on the Continuing Survey of Food Intake by Individuals (CSFII). Risk Analysis 1998, 18 (3), 283-291.

6. U.S. Department of Agriculture. Continuing Survey of Food Intakes by Individuals, Data Set and Documentation; Agriculture Research Service, Beltsville Human Nutrition Research Center: Beltsville, MD, 1989; p 74.

7. U.S. Department of Agriculture. Continuing Survey of Food Intakes by Individuals, Data Set and Documentation; Agriculture Research Service, Beltsville Human Nutrition Research Center: Beltsville, MD, 1990. 
8. U.S. Department of Agriculture. Continuing Survey of Food Intakes by Individuals, Data Set and Documentation; Agriculture Research Service, Beltsville Human Nutrition Research Center: Beltsville, MD, 1991.

9. $\quad$ Lindqvist, O.; Johannson, K.; Aastrup, M.; Andersson, A.; Bringmark, G.; Hovsenius, G.; Hakanson, L.; Iverfelt, A.; Meili, M.; Timm, B. Mercury in the Swedish Environment, Dordrecht; Kluwer: Netherlands, 1991.

10. National Research Council. Toxicological Effects of Methylmercury. National Academy Press: Washington, DC, 2000; pp 306-307; Library of Congress Card Number 00-108382. 